he knew what the history of the parties was; and if they were coming under his care he would be able to manage them better than a man at Gartnavel or Morningside, who had not a knowledge of those things.

Dr. Anderson said he should like to explain as to the Sheriff's warrant, that his opinion on the matter had been formed chiefly on account of the Wilson case.

The Chalryan said he thought that the meeting had already expressed their opinion fully as to their preference for the Bheriff's warrant rather than one by the justice of the peace.

Dr. Clouston said it was quite clear that there were many of the members whose opinions would be very valuable, who had not fully considered the con tents of the enormons Blue-book, and he thought they should therefore adjourn the discussion till the next meeting in Glasgow.

After some conversation, Dr. Clonston's snggestion was agreed to, and the Secretary was requested to endeavour to get some gentleman to bring forward a paper on the subject, as a basis for discussion.

$A$ vote of thanks to the President and Fellows of the Royal College of Phyricians, for the nse of their Hall, terminated the proceedings.

\title{
DR. C. LOCKHART ROBERTSON ON COUNTY LUNACY ADMINIS.
} TRATION.

The following letter from Dr. C. Lockhart Robertson appeared in the “Times," of March 22nd. It seems to us to contain most important sugges. tions of a highly practical kind, and we hope the Government may embody them in its Bill on the subject:-

TO TH: EDITOR OF THE " TIMES."

SIR, - One of the important duties which will devolve on the new County Boards will be the administration of the county lunatic asylums. I venture, therefore, before the County Government Bill goes into Committee, to ask your attention to one important financial question relating to the maintenance of the insane poor-viz., the grant to the unions from the Consolidated Fund of 48. a week for each lunatic confined in the county asylums. When the Chancellor of the Exchequer in 1874 proposed this grant he was careful to inform the House that it was of a temporary and tentative kind, and a relief to the landed interest until such time us the promised measures relating to local government and local expenditure were matured. The County Prisons Bill-the first of these measures-is law, and in my humble judgment is a wise and sound financial measure. This County Government Bill is the next instalment of local financial reform, and under its provisions ought, I think, to be included the permanent adjustment of this grant of 48. a week to each lunatic in the county asylum -a grant amounting last year to 2380,000 ; while if the recent very influential deputation which waited upon the President of the Local Government Board were successful in procuring its extension to the lunatics in workhouses it would soon be doubled.

When this grant was first proposed by the Government you permitted me in a short letter in the "Times" to express a fear that the union authorities might be tempted by the 4s. profit to fill the county asylums with the chronic lunatics detained in the union houses, and that thus this grant-given in relief-would ultimately increase the charge on the county rate by the required extensions of the lunatic asylums. Practically throughout the county asylums I have observed such unnecessary filling up of the wards by incurable lunatics and imbeciles from the workhouses to have been steadily and needlessly practised. In the report of the Lunacy Commissioners for 1876, I find this opinion confirmed. "It seems probable (they state) that the pecuniary advantage to unions

XXIV. 
arising out of the Parliamentary grant of 4s. per head per week for every pauper patient maintained in an asylum has in some counties contributed to increase the number in these institutions by the removal thereto of many patients who but for such inducement would have been retained in workhouses." So again Mr. Sclater-Booth, in his 16th report of the Visitors of the Hayward. Heath Asylum, writes :- "There are 43 more patients in this nsylum than there were a year ago. In any enquiry into the causes which may have contributed to this increase the Committee consider that the action of the Government in making an allowance of 48 . per week to the several unions for every pauper lunatic in the asylum ought not to be lost sight of."

The opportunity to which the Chancellor of the Exchequer looked of placing this 48. tentative grant towards the county lunacy expenditure on a sound and permanent basis is offered in this County Government Bill. The suggestion I venture to offer is that the amount of the grant instead of going to the union guardians be paid by the Treasury to the new County Boards, to be applied to the payment of two important items in the county asylum maintenance rateviz., the salaries, wages, and pensions, which now average under 3s. per week and, secondly, the repairs, alteratior.s, and future extensions of the fabric. which the remaining shilling of the 4s. grant would amply cover. The several unions would thus receive a permanent reduction of 38 . a week on the asylum main. tenance rate, which would then average from 68 . to 78 ., while the county rate would be directly relieved of the large sums yearly spent on repair, alteration, and enlargement of the asylum fabric. Thus, when the original cost of construction extended under the Act of 1845 to 30 years is once paid off, the care and treatment of the insane poor would no longer be a yearly item in the county expenditure, and the unions would have their lunatics treated and cured for the small charge of 7s. per week. So altered and applied, the Government grant of 48. from the Consolidated Fund would be a direct and permanent relief to the county expenditure, and the needless crowding of the asylum wards with chronic and imbecile cases would cease.

Should this proposal find favour with the Government and the House, I would add one further suggestion, which would moreover meet the views of the important deputation of the Medico-Psychological Association which last week had an interview with Mr. Sclater-Booth. According to my proposal the salaries, wages, and pensions of the staff of the county Asylums would be defrayed from the 4s. grant from the Consolidated Fund. Following the analogy of the Prisons Bill (as also of the Poor Law administration) I would suggest that the Government, us represented by the Lunacy Commissioners, should control the appointment and discharge of their officers and servants by the Lunacy Committee of the new County Boards, as also the grant of superannuation pensions under the Lunacy Acts. The fixity of tenure-especially as regards the medical superintendent- of office which this control of the Lunacy Commissioners would imply can hardly be over.rated in its influence on the well being and good management of the county asylum. Again, the fears expressed by the deputation of the Medico-Psychological Association as to their superannuation allowance would be allayed by my proposal to transfer this charge from the asylum union rate to the grant from the Consolidated Fund.

I am, Sir, your obedient servant,

Athenæum Club, March 9.

C. LOCKHARt Robertson.

\section{TEARLESS MADNESS}

As an example of the rubbish that passes current in even Medical Journals for Medico-Psychological facts, we quote the following annotation :-

"One of the most curious facts connected with madness is the utter absence of tears amidst the insane. Whatever the form of madness, tears are conspicuous by their absence, as much in the depression of melancholia, or the excitement of 